\title{
Correlation Between Coping Mechanism and Readiness of Midwifery Students for Taking Academic Examination
}

\author{
* $1^{\text {st }}$ Nur Laeli Rokhmah \\ Midwifery Program \\ Universitas 'Aisyiyah Yogyakarta \\ Yogyakarta, Indonesia \\ nurlaelirokhmah89@gmail.com
}

\author{
$2^{\text {nd }}$ Nuria Muliani \\ Nursing Program Study \\ Universitas Muhammadiyah Pringsewu \\ Lampung, Indonesia \\ nuria.muliani@yahoo.com
}

\author{
$3^{\text {rd }}$ Arena Lestari \\ Nursing Program Study \\ Universitas Muhammadiyah Pringsewu \\ Lampung, Indonesia \\ arena_lestari@yahoo.co.id
}

\begin{abstract}
Lack of psychological readiness causes students to fear their failure in facing the final exams. This relates to the ability of different coping mechanisms in students. The purpose of this study was to determine the correlation between coping mechanism and readiness of midwifery students for taking academic examination. This study applied a crosssectional study. This study involved 80 first semester midwifery students. Data collection used a questionnaire. Data analysis using Chi Square. The results of the analysis showed adaptive coping mechanism as many as 59 people $(\mathbf{7 3 . 7 5 \%})$, readiness of students facing exams as many as 26 people $(32.5 \%)$ and chi square value of 0.44 means that there was no meaningful relationship between student coping mechanisms and student's readiness in facing an exam. There needs to be awareness and support from lecturer so that students are able to manage their mentality to face changing situations and able to develop adaptive coping mechanisms.
\end{abstract}

Keywords-Coping mechanism, Readiness, Taking academic examination

\section{INTRODUCTION}

Every individual in life is always faced with various problems. Each stage of human growth and development will deal with problems that occur in different ways depending on the ability and experience in solving problems that arise. There is no individual who can be exactly the same in dealing with any situations. This relates to a person's coping abilities formed from an early age, where coping abilities are obtained through a learning process, drawing experience from their environment. Thus, every person has certainly different problems and how to solve them. When people are babies, they face problems with hunger and thirst, and they resolve by crying, so do teenagers who are still in school age certainly have different ways of solving problems [1][3].

Problems that are often felt by adolescents who are studying in the early period at the College are problems in adaptation with new friends, social culture, new learning methods, new exam models and many other things that can be the source of problems. Various problems that arise at the beginning of the lecture period become more severe if students are unable to adjust, even if adaptation cannot be carried out until before the semester examination period for the first time [4][8].
Each student must pass an exam which becomes one of the stages that must be taken by students to assess semester learning outcomes. The examination process is one source of stress for students, if not anticipated from the beginning it can affect a teen's self-concept. Because if someone fails in taking the test, they will feel inferior and different from their friends [9][14].

Individual efforts in adaptation can be in the form of changes in ways of thinking (cognitive), changes in behavior or changes in the environment aimed at resolving the stresses faced, and effective coping will produce adaptation. While ineffective individual coping is damage to adaptive behavior and the ability to solve problems from someone in dealing with demands and roles in life. Due to many tasks that must be completed, students should be able to accept all of these tasks as their obligations and responsibilities. However, in carrying out all these obligations and responsibilities, there are some students who consider it as a burden to themselves or as a pressure that causes stress for him/her. Lack of psychological readiness sometimes causes students to fear failure in facing the end of semester exams [1][3][15].

According to Garber's (2017) study, stress acceptance is significantly higher than the standard population, which is $81 \%$ of 368 students. Adaptive coping, acceptance and planning mechanisms that are most often done by students compared to maladaptive coping mechanisms, self- blame and behavioral release are associated with higher stress scores [2].

Factors that influence psychological readiness in dealing with stressors are maturity, motivation, and training, while the factors that influence coping mechanisms are family, psychological, physical activity, environmental factors, factors of knowledge level, nutrition and others. A person's coping mechanism will develop into a positive thing if the individual has a positive attitude towards all the problems that occur in him. However, each individual has different coping mechanism capabilities depending on the individual's background, one of which is the learning factor obtained from the environment about how to solve problems or problems [16][17].

Based on an initial survey of 10 students who will face semester exams for the first time, data obtained as many as 6 
people $(60 \%)$ said that they were not ready to take the exam, were very worried about not being able to graduate, so that they could not sleep, because they were afraid of not having time to sleep and to learn. While 4 people (40\%) said they were ready with the exam process, because they had tried their best to study seriously, think positively, and also pray a lot. Among 6 students who were not ready to take the exam, 5 students $(83 \%)$ had negative coping, and 1 student $(17 \%)$ had positive coping.

By seeing the above phenomenon, it is important to know the ability of student coping mechanisms so that we can approach psychologically to students who will face semester exams for the first time as a student. Therefore, the researcher wants to know the relationship between the coping mechanism of students and the readiness to face the end of the semester exams for Midwifery students at Universitas Muhammadiyah Pringsewu for the first time.

\section{METHOD}

\section{A. Desaign and Sampling}

This study used a quantitative, cross- sectional design. The purpose of this study was to determine correlation between coping mechanism and readiness of midwifery students for taking academic examination. The sampling technique applied a total sampling of 80 students.

\section{B. Participant recruitment}

Respondents meet the inclusion criteria if they were active midwifery study program students in the first semester of the 2015/2016 academic year and were willing to become respondents. Announcement and recruitment of respondents were conducted in the first semester midwifery student class. This study was approved by the Universitas Muhammadiyah Pringsewu Research Bureau. Before conducting research, researchers provide letters of approval to respondents in accordance with research criteria. The researcher explains the purpose and benefits of the research. Respondent has the right to refuse or agree to be involved in this research. This study guarantees the confidentiality and security of respondent data by giving initials or codes to respondents. Research conducted does not endanger respondents.

\section{Data Collection}

Data collection used a questionnaire. There were 4 sheets; the first sheet was about the respondent's identity, the second to the third sheet were a coping mechanism questionnaires using The ways of coping Questionnaire (Folkman and Lazarus, 1988), and the fourth sheet was the readiness questionnaire. The questionnaire consisted of 2 variables, namely an independent variable about coping mechanisms, measured through respondents' answers to questionnaire questions about coping mechanisms according to the Likert scale: 0: No; 1: A little; 2: Sometimes; 3: Yes. Summing the score of the questionnaire answers is categorized into 2, namely: adaptive coping mechanism if the score $\geqslant$ mean / median and maladaptive coping mechanism if the score $\leqslant$ mean / median [18]; The dependent variable about test readiness, measured by respondents' answers to the questionnaire questions about test readiness according to the Guttman scale: 1: No; 2: Yes.
Summing the score of the questionnaire answers is categorized into 2 namely: ready if the score is mean / median and not ready if the score is mean / median.

\section{Data Analysis}

All analyzes were performed using SPSS software ver. 20.0. The data is processed in advance using descriptive test statistics to explore data on the number of coping mechanisms and readiness to face the test. Bivariate analysis is used to test the hypothesis; if there is a relationship between the two variables, using the chi-square test (X2). There is a significant relationship between the two variables if the $\mathrm{p}$-value $\leqslant 0.05$.

\section{RESULT}

Descriptive and bivariate analysis

TABLE I. COPING MECHANISM

\begin{tabular}{|c|l|c|c|}
\hline No & \multicolumn{1}{|c|}{$\begin{array}{c}\text { Coping } \\
\text { Mechanism }\end{array}$} & Frequency & $\begin{array}{c}\text { Percentage } \\
(\boldsymbol{\%})\end{array}$ \\
\hline 1 & Adaptive & 59 & 73.75 \\
\hline 2 & Maladaptive & 21 & 26.25 \\
\hline \multicolumn{2}{|c|}{ Total } & 80 & 100 \\
\hline
\end{tabular}

Table 1 shows that the majority of midwifery coping mechanisms students are adaptive coping mechanisms as many as 59 students $(73.75 \%)$.

TABLE II. READINESS

\begin{tabular}{|c|l|c|c|}
\hline No & \multicolumn{1}{|c|}{ Readiness } & Frequency & Percentage (\%) \\
\hline 1 & Ready & 26 & 32.5 \\
\hline 2 & Not Ready & 44 & 67.5 \\
\hline \multicolumn{2}{|c|}{ Total } & 80 & 100 \\
\hline
\end{tabular}

Table 2 shows that most of the readiness of midwifery students facing the final semester exams is not ready as many as 44 students $(67.5 \%)$.

TABLE III. ANALYSIS OF COPING MECHANISM AND READINESS

\begin{tabular}{|c|c|c|c|c|c|c|c|}
\hline \multirow{3}{*}{$\begin{array}{l}\text { Mekanisme } \\
\text { koping }\end{array}$} & \multicolumn{4}{|c|}{ Mental Readiness } & \multirow{2}{*}{\multicolumn{2}{|c|}{ Total }} & \multirow{3}{*}{$\begin{array}{c}P \\
\text { Value }\end{array}$} \\
\hline & \multicolumn{2}{|c|}{ Ready } & \multicolumn{2}{|c|}{ Not Ready } & & & \\
\hline & $\mathbf{N}$ & $\%$ & $\mathbf{N}$ & $\%$ & $\mathrm{~N}$ & $\%$ & \\
\hline Adaptif & 31 & 52.5 & 28 & 47.5 & 59 & 73.75 & \\
\hline Mal adaptif & 5 & 23.8 & 16 & 76.2 & 21 & 26.25 & \\
\hline Total & 36 & 45 & 44 & 100 & 80 & 100 & \\
\hline
\end{tabular}

Table 3. Show that there is no correlation between coping mechanism and readiness of midwifery students for taking academic examination with a P-value of 0.44 .

\section{DISCUSSION}

Based on the results of bivariate analysis between coping mechanisms and students 'readiness to face final semester I exams, the p-value is 0.44 (greater than alpha $=0.05$ ), which 
means there is no meaningful correlation between coping mechanism and readiness of midwifery students for taking academic examination. This is not in line with Labrague's research (2017) which shows that students use both adaptive and maladaptive coping mechanisms in dealing with stressful events (such as in readiness to take an exam) depending on their situation and choice. Coping is the process that an individual goes through in resolving stressful situations. The coping is an individual's response to situations that threaten him/her both physically and psychologically [1], [3], [19], [20].

Adaptive coping mechanism is a coping mechanism that supports the integration function of learning growth and achieving goals. The categories are discussing to others, solving problems effectively, relaxation techniques and constructing activities. Coping responses differ greatly among individuals and often relate to individual perceptions of stressful events. Coping can be identified through responses, manifestations (signs and symptoms) and client statements in interviews [21].

In the opinion of researchers, this is based on the scientific view that basically every individual who is able to go through the process of growth and development well means that the individual has adaptive coping. This means that a student who is able to pass the examination at the College means at least an individual who has a good mechanism so that when examined in detail, it is proper for an individual / student to have adaptive coping. It is natural that at the beginning of the semester students will go through a difficult learning process, including facing a semester exam for the first time. Many different ways of learning and the methods used when compared with the period of education in high school. The difference in this condition is perceived as a sense of fear in facing of external stressors so that students tend to be unprepared [21]. Readiness is the closeness of an individual to the learning goals that are determined by feelings or circumstances for the actions needed. Students 'readiness in facing practice or examinations relates to students' perceptions, experiences, comfort and confidence. Increasing the perception of student readiness both in facing exams and clinical practice is very important. This relates to students' beliefs and motivations in learning and practicing. When their beliefs are good, they are able to increase their confidence to always provide the best performance so that students show an increased commitment to use their skills well [22]-[26].

According to the researcher, it shows that most midwifery study program students at Muhammadiyah Pringsewu University live in a dormitory, and students do not live with their parents, so they have to deal with individuals of varying nature and behavior. It needs a long adjustment process. In the first semester the adaptation process still dominates, so students have not been able to mentally manage the changing situations. Adaptive coping mechanism that is owned by a person does not guarantee to be able to solve all the problems that are owned, if the coping mechanism that has been owned is not developed or managed properly. Therefore it is necessary to have positive steps from various parties responsible for the education of a student to continue to work on strengthening the coping that is owned by students so that they can take advantage of coping in solving problems encountered, one of which is readiness to face the exam.

\section{CONCLUSION}

The adaptation process still dominates the readiness of students in facing exams. This needs awareness and support from lecturer so that students are able to mentally manage the changing situations and be able to develop adaptive coping mechanisms. Further researches require a qualitative study to analyze the strengthening of student coping mechanisms through the utilization of counseling guidance bureau in the University.

\section{ACKNOWLEDGMENT}

Our sincere appreciation to all participants who were involved in this research.

\section{REFERENCES}

[1] L. J. Labrague, D. M. McEnroe- Petitte, D. Gloe, L. Thomas, I. V. Papathanasiou, and K. Tsaras, "A literature review on stress and coping strategies in nursing students," J. Ment. Heal., vol. 26, no. 5, pp. 471-480, 2017, doi: 10.1080/09638237.2016.1244721.

[2] M. C. Garber, "Exercise as a stress coping mechanism in a pharmacy student population," Am. J. Pharm. Educ., vol. 81, no. 3, pp. 1-6, 2017, doi: 10.5688/ajpe81350.

[3] B. McCarthy et al., "Nursing and midwifery students' stress and coping during their undergraduate education programmes: An integrative review," Nurse Educ. Today, vol. 61, no. October 2016, pp. 197-209, 2018, doi: 10.1016/j.nedt.2017.11.029.

[4] A. V. Sarmiento, M. V. Pérez, C. Bustos, J. P. Hidalgo, and J. I. V. del Solar, "Inclusion profile of theoretical frameworks on the study of sociocultural adaptation of international university students," Int. J. Intercult. Relations, vol. 70, no. February, pp. 19-41, 2019, doi: 10.1016/j.ijintrel.2019.02.004.

[5] S. Y. Park and J. H. Kim, "Campus Life Adaptation Scale for nursing undergraduates: Development and psychometric evaluation," Nurse Educ. Today, vol. 79, no. March, pp. 56-62, 2019, doi: 10.1016/j.nedt.2019.05.014.

[6] D. Iordan, G. Roth, and B. Vivona, "Becoming a Nursing Program Graduate: Transitions and Adaptations by Eastern European Immigrant Students of a Midwest Community College," Teach. Learn. Nurs., vol. 15, no. 1, pp. 72- 76, 2020, doi: 10.1016/j.teln.2019.10.001.

[7] H. J. M. Pennings, M. Brekelmans, P. Sadler, L. C. A. Claessens, A. C. van der Want, and J. van Tartwijk, "Interpersonal adaptation in teacher- student interaction," Learn. Instr., vol. 55, pp. 41-57, 2018, doi: 10.1016/j.learninstruc.2017.09.005.

[8] R. Z. Peng and W. P. Wu, "Measuring communication patterns and intercultural transformation of international students in cross- cultural adaptation,” Int. J. Intercult. Relations, vol. 70, no. March, pp. 78-88, 2019, doi: 10.1016/j.ijintrel.2019.03.004.

[9] F. Nofriza and D. D. Sagita, "Differences wellness among students in guidance and counseling major FKIP UHAMKA Early And Year End Year Class,” Int. J. Res. Couns. Educ., vol. 1, no. 2, p. 40, 2018, doi: 10.24036/0020za0002.

[10] L. Cilar, O. Barr, G. Štiglic, and M. Pajnkihar, "Mental well-being among nursing students in Slovenia and Northern Ireland: A survey," Nurse Educ. Pract., vol. 39, no. March, pp. 130-135, 2019, doi: 10.1016/j.nepr.2019.07.012

[11] S. Lavy and E. Naama-Ghanayim, "Why care about caring? Linking teachers' caring and sense of meaning at work with students' selfesteem, well-being, and school engagement," Teach. Teach. Educ., vol. 91, p. 103046, 2020, doi: 10.1016/j.tate.2020.103046.

[12] Z. S. Li and F. Hasson, "Resilience, stress, and psychological wellbeing in nursing students: A systematic review," Nurse Educ. Today, vol. 90, no. April, p. 104440, 2020, doi: 10.1016/j.nedt.2020.104440.

[13] Y. Alshahrani, L. Cusack, and P. Rasmussen, "Undergraduate nursing students' strategies for coping with their first clinical placement: 
Descriptive survey study,” Nurse Educ. Today, vol. 69, no. June, pp. 104-108, 2018, doi: 10.1016/j.nedt.2018.07.005.

[14] N. Rehmani, Q. ul A. Khan, and S. Fatima, "Stress, anxiety and depression in students of a private medical school in Karachi, Pakistan,” Pakistan J. Med. Sci., vol. 34, no. 3, pp. 696-701, 2018, doi: $10.12669 /$ pjms.343.14664.

[15] B. A. et. all KELIAT, Keperawatan Kesehatan Jiwa Komunitas: CMHN (Basic course). Jakarta: EGC, 2013.

[16] C. Saravanan, M. Mohamad, and A. Alias, "Coping strategies used by international students who recovered from homesickness and depression in Malaysia," Int. J. Intercult. Relations, vol. 68, no. November 2018, pp. 77-87, 2019, doi: 10.1016/j.ijintrel.2018.11.003.

[17] K. C. Herman, S. L. Prewitt, C. L. Eddy, A. Savale, and W. M. Reinke, "Profiles of middle school teacher stress and coping: Concurrent and prospective correlates," J. Sch. Psychol., vol. 78, no. June 2018, pp. 54-68, 2020, doi: 10.1016/j.jsp.2019.11.003.

[18] Folkman and Lazarus, "The Ways of Coping Questionnare," 1988.

[19] L. Wolf, A. W. Stidham, and R. Ross, "Predictors of Stress and coping strategies of US Accelerated vs. Generic baccalaureate nursing students: An embedded mixed methods study," Nurse Educ. Today, vol. 35, no. 1, pp. 201-205, 2015, doi: 10.1016/j.nedt.2014.07.005.
[20] F. F. Zhao, X. L. Lei, W. He, Y. H. Gu, and D. W. Li, "The study of perceived stress, coping strategy and self-efficacy of Chinese undergraduate nursing students in clinical practice," Int. J. Nurs. Pract., vol. 21, no. 4, pp. 401-409, 2015, doi: 10.1111/ijn.12273.

[21] P. J. Stuart GW, Keliat BA, Prinsip dan praktik Keperawatan Kesehatan Jiwa Stuart. Indonesia: Elsevier, 2016.

[22] F. P. Gail Williams, MD, FAAP, a Marc Alan Lerner, MD, "School Readiness," Am. Acad. Pediatr., 2019, doi: https://doi.org/10.1542/peds.2019- 1766.

[23] B. Patterson, "Facilitator."K.

[24] Casey, R. Fink, C. Jaynes, L. Campbell, P. Cook, and V. Wilson, "Readiness for practice: The senior practicum experience," J. Nurs. Educ., vol. 50, no. 11, pp. 646-652, 2011, doi: 10.3928/0148483420110817-03.

[25] N. Mirza, L. Manankil-Rankin, D. Prentice, L. A. Hagerman, and C. Draenos, "Practice readiness of new nursing graduates: A concept analysis," Nurse Educ. Pract., vol. 37, no. March 2018, pp. 68-74, 2019, doi: 10.1016/j.nepr.2019.04.009.

[26] H. E. Monroe, "Determining Readiness To Take the National Council Licensure Examination for Registered Nurses. Dissertation,” pp. 1$141,2019$. 